http://dx.doi.org/10.12775/szhf.2015.032

\author{
FALK HORST \\ Freundeskreis Panajotis Kondylis e.V, Heidelberg \\ FALKHORST@GMX.DE \\ Konstantin Verykios \\ LEFKAS (GRECJA) \\ FAM.COSVER@YAHOO.GR \\ LECH ZIELIŃSKI \\ Uniwersytet MikoŁaja Kopernika, Toruń \\ LECH.ZIELINSKI@UMK.PL
}

\title{
Obserwacja rzeczywistości a tworzenie teorii w myśli Panajotisa Kondylisa
}

\section{Wprowadzenie}

Jesienią 1998 roku w Atenach, tuż po śmierci Panajotisa Kondylisa, Reinhard Koselleck w swojej mowie na cześć zmarłego, w której nawiązał do ar-

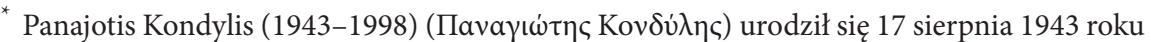
w Olimpii w Grecji. Dorastał w Atenach, gdzie studiował filologię klasyczną i filozofię (1963-1967). Już jako student tłumaczył na język grecki teksty wielkich europejskich autorów historii myśli. Działalność tę kontynuował również po studiach. Dwa lata po odbyciu służby wojskowej (1967-1969) wyjechał do Niemiec, gdzie studiował na uniwersytetach w Heidelbergu
} 
tykułów Kondylisa opracowanych do leksykonu Geschichtliche Grundbegriffe. Historisches Lexikon zur politisch-sozialen Sprache in Deutschland ${ }^{1}$ (Leksykon historyczny języka polityczno-społecznego Niemiec), wyraził następującą myśl:

[...] Panajotis Kondylis żył 55 lat (1943-1998). Jego intensywne życie było wystarczająco długie, by obdarować nas, którzy go przeżyliśmy, swoją twórczością, z której będziemy jeszcze długo czerpać, niezależnie od tego, czy przyjmiemy pozycję krytyczną czy aprobującą. Jego twórczość w każdym wypadku zmusza do dalszego myślenia. Zarazem jego życie było także zbyt krótkie, by mógł on ukończyć swoje dzieło² (przeł. L. Z).

Dziś można powiedzieć, że sąd Kosellcka o twórczości Kondylisa pozostaje nadal aktualny. W myśli tego filozofa można bowiem znaleźć zarówno trafną prognozę współczesnego rozwoju świata i nadciągających konfliktów, których dziś niestety jesteśmy świadkamiª jak i trafne oceny i ujęcia dale-

i Frankfurcie nad Menem. Przedmiotem jego studiów w Republice Federalnej Niemiec były filozofia, historia i politologia. W roku 1971 opublikował książkę na temat Machiavellego, a po sześciu latach dalszych intensywnych badań obronił w Heidelbergu swoją rozprawę doktorską na temat powstania dialektyki, której promotorem był Dieter Henrich. Jego doktorat opublikowano w postaci dwóch odrębnych książek: Die Entstehung der Dialektik oraz „Die europäische Aufklärung im Rahmen des neuzeitlichen Rationalismus, które szybko stały się standardem. W latach 70. i 80. XX wieku oprócz pracy naukowej dokonał przekładu na język grecki dzieł wielu znanych autorów (Karol Marx, Ernst Cassirer, Carl Schmitt, Max Horkheimer, Arnold Hauser, Nicollo Machiavelli). Jego kolejne bardzo szeroko zakrojone prace, jak choćby: Die neuzeitliche Metaphysikkritik, Die Theorie des Krieges, Konservativismus, Der Niedergang der bürgerlichen Denk- und Lebensform, Planetarische Politik nach dem Kalten Krieg ukazały się w latach 80. i 90. XX wieku. Praca nad dziełem życia Ontologia społeczna, zaplanowana na trzy wielkie tomy, została przerwana na zawsze w dniu 11 lipca 1998, kiedy w pełni sił twórczych niespodziewanie odszedł z tego świata. Osobom mu bliskim udało się opublikować w 1999 roku (zgodnie z planem Kondylisa) pierwszy tom tego dzieła. (Najbardziej szczegółowe ustalenia dotyczące życia Kondylisa znajdują się w nieopublikowanej pracy magisterskiej Giseli Horst Leben und Werk des Philosophen und Gesellschaftsdenkers Panajotis Kondylis (1943-1998), której promotorem był syn byłego kanclerza Niemiec, profesor historii Peter Brandt (obrona 6 sierpnia 2013 r.).

${ }^{1}$ Geschichtliche Grundbegriffe, Historisches Lexikon zur politisch-sozialen Sprache in Deutschland, red. R. Koselleck et al., Stuttgart 1972-1997.

2 Por. R. Koselleck, Kondylis' Beiträge zu den geschichtlichen Grundbegriffen, [w:] Panajotis Kondylis Aufklärer ohne Mission. Aufsätze und Essays, Berlin 2007, s. 1.

${ }^{3}$ Mamy tu na myśli przede wszystkim książkę Kondylisa Planetarische Politik nach dem Kalten Krieg, Berlin 1992 oraz książkę wydaną pośmiertnie w języku nimieckim Das Politische im 20. Jahrhundert. Von den Utopien zur Globalisierung, Berlin 2001. 
kiej przeszłości, które zostały uznane za standardowe ${ }^{4}$. Choć myśl Kondylisa nie jest w Polsce zupełnie nieznana, o czym świadczyć mogą dość obszerny artykuł Illiasa Wrazasa Nihilizm i teoria. Panajotisa Kondylisa dyskryptywna teoria decyzji, opublikowany w czasopiśmie filozoficznym „Nowa Krytyka” w 2005 roku oraz artykuł Tomasza Gubisia z 2006 roku, to jednak stwierdzić należy, że poziom recepcji myśli Kondylisa w naszym kraju jest nadal bardzo niski. Próba zorganizowania poświęconej mu większej polsko-niemiecko-greckiej konferencji, mimo dużego nakładu pracy, na pewno nie zakończyła się sukcesem 5 .

\section{Garść uwag wprowadzających do myśli Kondylisa}

Greccy filozofowie często wyróżniają się odważnymi ideami, dotyczy to także Panajotisa Kondylisa. Stosunkowo wcześnie udało mu się uwolnić od wielu znanych $\mathrm{z}$ historii filozofii błędów w rozumowaniu. Błędy dotyczą już starego jak świat sporu między Platonem a sofistami, którego skutki do dzisiaj widoczne są w debatach filozoficznych. Obie strony nie odróżniały sceptycyzmu poznania rozumowego od sceptycyzmu odnoszącego się do

\footnotetext{
${ }^{4}$ Wspomnieć tu wystarczy jego dzieło na temat oświecenia, wydane po raz pierwszy w Stuttgarcie w wydawnictwie Klett-Cotta pod tytułem Die Aufklärung im Rahmen des neuzeitlichen Rationalismus w 1981 roku, a następnie wznawiane w roku 1986, 1998 (wydanie greckie) oraz 2002, które szybko stało się jedną z najważniejszych pozycji niemieckojęzycznych poświęconych tej tematyce oraz studium na temat konserwatyzmu Konservatismus, Geschichtlicher Gehalt und Untergang, wydane po raz pierwszy w Stuttgarcie w $1986 \mathrm{r}$. Na temat tej ostatniej pozycji sporo informacji w artykule T. Gabisia, Panajotis Kondylis, „Nowe Państwo”, 2006, nr 3.

${ }^{5}$ Jak już wspomniano, w Polsce zorganizowano dwie konferencje poświęcone Kondylisowi. Pierwsza z nich niewątpliwie odniosła pewien sukces, choć zapowiedź Dyrektora Instytutu Kulturoznawstwa WSG Marka Chamota: „w środowisku bydgoskich naukowców poczytujemy sobie za zaszczyt, iż możemy (jako pierwsi!) zaprezentować postać i dorobek prof. P. Kondylisa na gruncie polskiej nauki” była lekką przesadą. Niemniej prawdą jest, że udało się pozyskać, przede wszystkim z Niemiec, kilka znaczących osób (Dietrich Harth, Ulrich Fröschke, Andreas Cser, Falk Horst, Anna Lazau, Gisela Horst), a wygłaszane w trzech językach referaty robiły bardzo dobre wrażenie. Współpraca ta była zasługą Evangelosa Spyropoulosa, emerytowanego profesora historii, króry przez przyjazną znajomość z Markiem Chamotem i Lechem Zielińskim uczestniczył w ich wcześniejszych projektach naukowych. Niemniej fakt, że wygłoszonych referatów nie opublikowano oraz to, że ze strony polskich uczestników jedynie Zieliński przedstawił temat związany bezpośrednio z myślą Kondylisa, wskazują wyraźnie, że mamy do czynienia dopiero z początkiem recepcji Kondylisa w Polsce.
} 
wartości. Platonicy wyjaśniali, że zmysłowe postrzeganie jest niepewne, natomiast pewna jest sama niezmienność dóbr. Sofiści z Protagorasem na czele przeciwstawiali temu twierdzeniu sceptyczną tezę, jakoby nie istniał żaden obiektywizm ani w aspekcie poznawczym, ani etycznym. W swej polemice platonicy i sofiści, zdaniem Kondylisa, w sposób niedopuszczalny posługiwali się analogiami między płaszczyzną poznawczą i etyczną.

Zgodnie $\mathrm{z}$ hermeneutycznymi założeniami Kondylisa w sporze tym, podobnie jak w wielu innych, polemika dominuje nad logiką. $Z$ relatywizmu wartości nie da się bowiem wyciągnąć, jak chcieli to zrobić sofiści, logicznego wniosku o niemożliwości obiektywnego, a tym bardziej pewnego, rozpoznania świata. Błąd ten jest wynikiem przedkładania polemiki nad logikę. Inny argument jest wymierzony przeciw epistemologicznemu sceptycyzmowi. Gdyby ze sceptycznej perspektywy wszystkie inne stanowiska były względne, to relatywizm obowiązywałby w takim przypadku także przedstawicieli sceptycyzmu. Wniosek ten jest jednak z punktu widzenia logiki fałszywy. Bo jeżeli twierdzi się, że prawdziwa jest teoria przyjmująca, że wyobrażenia na temat świata są względne, a w następnym zdaniu wnioskuje się, że zatem względna jest także ich teoria, to popada się w sprzeczność, ponieważ w pierwszym zdaniu za prawdziwe uznaje się to, co odrzuca się w zdaniu drugim. Choć wielokrotnie dowodzono błędności tego rozumowania, błąd ten jest obecny we współczesnych dyskusjach do dziś. Niedawno przedstawił go Oliver Flügel-Martinsen ${ }^{6}$, przeciwstawiając się sceptycyzmowi Kondylisa i dał tym samym przykład na to, jak łatwo potrzeba polemiki może zniweczyć potrzebę poprawnego wywodu logicznego. Zgodnie z przekonaniem Kondylisa, w argumentacji, po którą sięga się w sporach filozoficznych, nie przyjmuje się pozycji moralnego sceptycyzmu, ponieważ życie społeczne wymaga istnienia wartości, ewentualnie ich ustanawiania. Dlatego też Protagoras był w trudnej sytuacji. $Z$ drugiej strony każdy naukowiec musi w swojej pracy dążyć do uwolnienia się od wartości, ponieważ w miarę możliwości powinna być ona obiektywna. Z pragmatycznego punktu widzenia dążenie to ma pewien sens, ale nie przedstawia żadnej wartości etycznej. Dlatego między społeczną codziennością a prawem naukowca istnieje przepaść nie do przezwyciężenia. Wypieranie się „obiektywnych wartości” charakteryzuje postawę czysto naukową, która w żadnym społeczeństwie nie powinna być niczym innym, jak tylko neutralną postawą obserwatora. Gdyby jednak dotyczyła innych obsza-

${ }^{6}$ Por. Apodiktischer Dezisionismus? Kondylis' Machtdenken, „Deutsche Zeitschrift für Philosophie“, 2012, 3, s. 364 n. 
rów życia, miałaby działanie destrukcyjne. Jak już wspomniano, sceptycyzm wobec wartości pozwala na taką analizę cech charakterystycznych ludzkiego zachowania, której nie dałoby się przeprowadzić z perspektywy normatywno-etycznej. Abyśmy mogli uporać się z codziennością, wyznawane przez nas wartości muszą stwarzać wrażenie obiektywnych, w przeciwnym bowiem razie wielu ludzi miałoby problemy z nadaniem sensu własnemu życiu; sensu tego potrzebuje także przedstawiciel sceptycyzmu, upatrujący swojego głównego celu działania w poszukiwaniu prawdy. Dla potrzeb swego codziennego życia musi on przezwyciężyć logiczną konsekwencję sceptycyzmu. Oparcie opisu świata na normach uniemożliwia rozpoznanie podstawowych struktur ludzkiego zachowania.

Sceptyczny punkt widzenia jest także uwarunkowany historycznie. Pozycja sceptyka mogła rozwinąć się bowiem dopiero wówczas, gdy miała odniesienie do sporów różnych ideologii, stających się przedmiotem analizy i pytań o źródła ich skuteczności, potrzebę ich występowania itd. Owa postawa sceptyka jest postawą naukową, będącą warunkiem poszukiwania prawdy o ludzkich sprawach. Ludzie, jak wszystkie istoty żywe, dążą do przetrwania. Dla człowieka jako istoty społecznej dążenie to oznacza pragnienie posiadania władzy, bądź jej wzmocnienia, ponieważ jednostka chciałaby wyróżnić się na tle pozostałych i dlatego konkuruje $\mathrm{z}$ innymi. $\mathrm{W}$ ten sposób powstają konflikty, które napędzają dynamikę procesów historycznych. Dla Kondylisa natura ludzka posiada iście janusowe oblicze: „Społeczeństwo ludzi nie może żyć w stanie permanentnej wojny, nie rozpadając się, jednocześnie jednak nie może we własnym łonie nie rodzić konfliktów".

Kondylis kierował się takim sposobem myślenia, przedstawiając swą teorię decyzjonizmu deskryptywnego. Naukowiec ma prawo do neutralnego pod względem wartości opisu zjawisk jedynie wówczas, gdy w opisie ludzkich spraw założy, że wszelkie wartości mają charakter względny. Tym samym oddala się on od swojej społecznej codzienności, w której przyjmuje się obiektywnie istnienie wartości oraz sensu ludzkiego życia, będącego przedmiotem dążeń wszystkich ludzi. Świat musi być każdorazowo interpretowany w taki sposób, żeby orędownikom postulowanych ideałów ich własne dążenie do władzy wydawało się żądaniem historycznym, racjonalnym, a przede wszystkim moralnie uzasadnionym.

Kondylis uważa się za obserwatora ludzkich spraw i analityka konkretnych ludzkich zachowań. Nie obserwuje ich jednak z punktu widzenia socjologa czy filozofa; chodzi mu o jednolitość podstawowych struktur ludzkiego zachowania, objawiającą się w różnych naukach, ale także w praktyce 
filozoficznej, społecznej czy politycznej. Zgodnie z rezultatami jego dociekań zachowanie ludzkie w swej podstawowej strukturze jest we wszystkich dziedzinach takie samo. Głównym celem badacza jest zatem odkrycie owej podstawowej struktury i wyjaśnienie jej na konkretnych przykładach. Już w pracy doktorskiej poświęconej filozofii i historii idei Kondylis przedstawił uzasadnienie istnienia tej podstawowej struktury antropologicznej. Dzięki temu dowodowi udało mu się znaleźć w historii idei pewien motyw przewodni i wyjaśnić w przekonujący sposób to, co wcześniej pozostawało niewytłumaczalne. Jako obserwator ludzkich spraw Kondylis nie mógł zrezygnować z bacznego obserwowania otaczającej go codzienności, jednocześnie ustosunkowując się do wcześniej prowadzonych analiz, wyciąganych wniosków oraz sprawdzając ich spójność. Wykaz jego prac przekonuje, że pod kątem swoich własnych ustaleń przeanalizował wiele klasycznych dzieł filozoficznych, a jego centralnym obserwatorium stała się Biblioteka Uniwersytecka w Heidelbergu.

Wynik tych obserwacji jest między innymi następujący: nie istnieją żadne jednolite ramy argumentacyjne dla różnych filozofii, ponieważ konkurują one ze sobą. Nie tylko teorie filozoficzne, ale również społeczne, historyczne czy polityczne dają się zawsze wyprowadzić z wyobrażeń o charakterze normatywnym. Dla teorii różnych dziedzin ludzkiego działania wspólne jest to, że każdorazowo reprezentują one konkurujące ze sobą wyobrażenia normatywne.

Jeżeli stwierdzi się zgodność podstawowej struktury ludzkiego zachowania, opis powinien nastąpić na jakiejś płaszczyźnie odnoszącej się do wszystkich dziedzin ludzkiej działalności. Wybrane pojęcie musi być powszechnie zrozumiałe, a więc pokrywać się z potocznym użyciem języka. W przypadku czystego opisu należy unikać jakiegokolwiek normatywno-etycznego punktu widzenia. Wyniki są tym bardziej przekonujące, im więcej fenomenów zostanie wyjaśnionych dzięki teorii, ponieważ jest ona tym lepsza, im większa jest jej moc eksplanacyjna, gdy potrafi połączyć pozornie oddalone od siebie obszary ludzkiego działania i wypracować jednolite cechy charakterystyczne.

Metoda nie jest niezależna od merytorycznych założeń, których dotyczy i które musi także uzasadniać. Takim merytorycznym założeniem antropologicznym Kondylisa jest to, że określony, wynikający z decyzji o charakterze moralno-normatywnym sposób myślenia w ostateczności zawsze dąży do zdystansowania się od innych, a ponieważ zawsze istnieje pomiędzy nimi spór, ludzkie myślenie musi mieć charakter polemiczny. 
Każde podstawowe stanowisko zaczyna się od podjęcia określonej decyzji, która tak głęboko zakorzeniona jest w nieświadomości, że tylko częściowo jest dostępna dla rozumu. Wybrana w ten sposób wartość ma charakter aksjomatu i nie potrzebuje żadnego dowodu. Podjęcie owych decyzji umożliwia stworzenie względnie spójnego obrazu świata. Musi on zostać zbudowany w sposób logiczny, ponieważ w przeciwnym razie nie miałby siły przekonywania. Logika może być wykorzystywana w obronie całkiem różnych stanowisk lub światopoglądów. Charakter myślenia decyduje o tym, czy określone normy i wartości zostaną ustalone świadomie, czy milcząco przyjęte i czy staną się one przedmiotem badań.

Jeżeli chce się postępować w sposób czysto opisowy, czyli rezygnując z norm i wartości, wychodzi się z założenia, że nie istnieją one obiektywnie, lecz są ustanawiane przez nieuświadamiane lub świadome decyzje, charakterystyczne dla danego światopoglądu. Aby móc ich skutecznie bronić, trzeba je uznać za obiektywne, ponieważ w przeciwnym razie miałyby charakter względny, jawiąc się tym samym jako dowolne i zastępowalne. Taki punkt widzenia świata $\mathrm{z}$ jego normami ma szansę zyskać popularność, ponieważ czyni wrażenie obiektywnego. Próbuje się go wówczas ugruntować w „naturze”, „historii” lub „,naturze ludzkiej”, opisując każdorazowo z perspektywy określonych norm. (Wartości i normy powinny zostać odkryte lub zakorzenione w istnieniu, należy je „ontologizować”).

Różnorodne prace dotyczące historii idei i prądów intelektualnych stanowiły dla Kondylisa szeroką podstawę intelektualną, za pomocą której chciał pokazać, jak hermeneutycznie owocna jest jego teoria spraw ludzkich. W jednym z wywiadów wyjaśniał:

Jeżeli jakiemuś rozważaniu uda się połączyć i w spójny sposób ująć pozornie różne tematy oraz fenomeny, wtedy wiele otwarcie za nim przemawia. Metodologicznie zorientowane porównanie dzieł, takich jak Aufklärung (Oświecenie), Konservatismus (Konserwatyzm) lub Theorie des Krieges. Clausewitz - Marx Engels - Lenin pozwala uważnemu czytelnikowi wyjaśnić sposób, w jaki już wcześniej dokonano omówionego rozsadzenia granic między dyscyplinami. Nie chodzi tu oczywiście tylko i abstrakcyjnie o właściwą metodę, lecz o merytoryczne założenia, które sprawiają, że metoda ta staje się owocna. Czasami frustrująco szeroki zakres i szczegółowość moich dzieł o tematyce historycznej przesłaniają mój podstawowy zamiar i sprawiają, że moja ogólna idea wyłania się dopiero z ich całości. Tylko dokładna interpretacja całości prac może przekonać o trafności i rzeczowości mojej interpretacji. Tymczasem normatywne lub merytoryczne uprzedzenia $\mathrm{z}$ reguły idą $\mathrm{w}$ parze $\mathrm{z}$ selektywnym traktowa- 
niem materiału, co powoduje, że obalenie moich wyników jest uprawnione tylko na podstawie przynajmniej równie obszernej analizy materiałów. (Wywiad Marina Terpstry, w: „Machtfragen”, Darmstadt 2006, s. 160 n.)

Można to porównać do teorii względności, w której newtonowska fizyka dotyczy jedynie wąskiego wycinka rzeczywistości, a tym samym posiada mniejszą moc eksplanacyjną.

Podstawą dzieł Kondylisa dotyczących historii idei i prądów intelektualnych jest teoria powstała w wyniku badań przekraczających granice dziedzin, która została zbudowana na podwalinach niezwykle obszernych analiz historii prądów intelektualnych. Praca doktorska napisana w Heidelbergu, zapowiadająca jego najważniejsze dzieła, obejmuje dwa teksty: Die Entstehung der Dialektik. Eine Analyse der geistigen Entwicklung von Hölderlin, Schelling und Hegel bis 1802 (Powstanie dialektyki) i Die Aufklärung im Rahmen des neuzeitlichen Rationalismus (Oświecenie w ramach nowożytnego racjonalizmu); przed jej ukończeniem Kondylis zebrał już materiały do Die neuzeitliche Metaphysikkritik (Metafizycznej krytyki nowożytności). Dzieła te opisują świat ludzkiego ducha na podstawie wypracowywanej, wspomnianej teorii, przedstawionej następnie w Macht und Entscheidung (Władzy i decyzji). Praca ta zawiera streszczenie aktualnych do tego czasu antropologicznych teorii, do których Kondylis doszedł na podstawie swoich badań, rozwiniętych szczegółowo w nieukończonej książce Das Politische und der Mensch. Grundzüge der Sozialontologie ${ }^{7}$.

\section{Kondylisowska koncepcja tworzenia teorii}

Jak z obserwacji rzeczywistości, można stopniowo rozwinąć ogólną teorię, będącą przesłanką do tworzenia innych teorii, co wyjaśnił Kondylis na przykładzie przemyśleń teoretyka wojny Carla von Clausewitza, którego sposób myślenia był mu bliski.

${ }^{7}$ Dzieło Das Politische und der Mensch. Grundzüge der Sozialontologie było zaplanowane na trzy wielkie tomy o następujących tytułach: t. 1 - Soziale Beziehung, Verstehen, Rationalität, t. 2 - Gesellschaft als politisches Kollektiv, t. 3 - Identität, Macht, Kultur. Kondylis zdążył przed swoją przedwczesną śmiecią opracować prawie cały tom 1 (zabrakło około 10 stron ostatniego podrozdziału). Tom ten liczy 715 stron izostał wydany przez Falka Horsta rok po śmierci filozofa. 
Przyjmowane przez Clausewitza założenia dotyczące pracy naukowej przypominają późniejszy program Kondylisa: tylko dzięki rezygnacji z roszczeń do normatywności można uzyskać właściwe pojmowanie praktyki.

1. Nauka sama w sobie ma wartość, ponieważ teoria powinna być rozumiana jako obserwacja, a nie jako nauczanie.

2. Oceny i przyczynowe wyjaśnienia muszą się od siebie różnić.

3. Należy rozróżnić analizy moralne i historyczno-polityczne. Clausewitz uważa, że mamy do czynienia ze stworzeniem udanej teorii wtedy, gdy opisuje ona „zgodność myślenia spekulatywnego ze zjawiskami, porozumienie a nawet stopienie się «wymyślonego z istniejącym» przy jednoczesnym wskazaniu na zależność elementu spekulatywnego czy historycznego z naturą przedmiotu"s. Takie stopienie się jest możliwe tylko wówczas, gdy uniknie się bezowocnego teoretycznego empiryzmu z jednej strony i pustej spekulacji z drugiej.

Opierając się na przemyśleniach Kanta, można powiedzieć: opinia bez jej przyporządkowania do jakieś teorii jest ślepa, natomiast pojęcia bez opinii są puste. W procesie tworzenia teorii, bezpośrednie zjawisko odnoszące się do pojedynczego przypadku nie pomoże przy szukaniu związku pomiędzy rzeczami, odosobniony przypadek nie może być przyjmowany bezpośrednio i w niezmienionej formie włączony do konstrukcji teoretycznej. Teoria musi bowiem odnosić się do klas zjawisk. Są nimi fenomeny posortowane pod względem treści, „ich opracowanie mówi coś o strukturze i budowie wspomnianego przedmiotu poznania w jego całości" (Theorie des Krieges, s. 96-97).

„Postępu teorii nie osiąga się poprzez stworzenie dystansu względem omawianych zjawisk, lecz przez udoskonalenie ogólnych pojęć, które w dużej mierze powoduje zmniejszenie nieuniknionego dystansu do jednostki, umożliwiając w ten sposób skuteczne porównanie teorii $\mathrm{z}$ doświadczeniem” (Theorie des Krieges, s. 98).

Tym samym poruszone zostały główne warunki tworzenia teorii, mianowicie władza sądzenia i posiadana przez teoretyka językowa zdolność różnicowania. Podstawą badań Kondylisa były nie tylko teksty napisane w języku greckim, ale także po niemiecku, zwłaszcza te dotyczące historii prądów in-

${ }^{8}$ P. Kondylis, Theorie des Krieges. Clausewitz - Marx - Engels - Lenin, Stuttgart 1988, s. 96. Dalej podajemy jako Theorie des Krieges. 
telektualnych. W jednym z wywiadów wyjaśnił (Diavanzo nr 384, kwiecień $\left.1998^{9}\right)$ :

Początkowo miałem uprzywilejowany dostęp do języków starogreckiego i łacińskiego, które są systemami syntaktycznymi i gramatycznymi, charakteryzującymi się dobrze zorganizowanymi strukturami wyrażania myśli; ich gruntowna znajomość pozwoliła mi zrozumieć fenomen języka jako takiego. Języki, w których nie zostaną zatarte kontury znaczeniowe słów i zdań przez straszną i bezowocną mglistość nowszego subiektywizmu, przypominają trwałe mury, zbudowane z dużych kamieni, mające spojenia i stojące na stabilnej podstawie, posiadające $w$ swych rytach i dokładnym przekazie refleksji trwałe relacje pomiędzy określającym i określanym. Precyzja i prostota nie są żadnym zewnętrznie ustanowionym warunkiem, lecz wynikiem zachowania wewnętrznej

9 Tłumaczka dysponowała jedynie fragmentem niemieckiego tłumaczenia tego wywiadu, który faktycznie opublikowany został po raz pierwszy w greckim czasopiśmie „Diavazo” [dosłownie ja czytam], z. 384, s. 127-137). W przekładzie na język niemiecki dokonanym przez Anastasię Daskorolis i Konstantina Verykiosa fragment ten brzmi: Zuallererst bedeutet die Vertrautheit mit der altgriechischen und der lateinischen Sprache als syntaktischer und grammatischer Systeme und als entsprechend organisierter Ausdrucksmöglichkeiten für mich die große und disziplinierte Einweihung in das Phänomen „Sprache” allgemein, und zwar durch eine ganz privilegierte Annäherungsweise. Sprachen, in denen die Bedeutungskonturen der Wörter und Sätze nicht verwischt werden von - fruchtbaren oder unfruchtbaren - Nebulositäten des neueren Subjektivismus, ähneln zyklopischen Mauern, die mit Feldsteinen und mit sichtbaren Fugen und standfesten Stützen aufgeführt sind, mit stabilen Entsprechungen zwischen dem Bezeichnendem und dem Bezeichneten im Zurechtmeißeln der Sprache und dem genauen Ausrichten der Reflexion. Die Präzision und Schlichtheit sind hier keine von außen gestellten Forderungen, sondern ein Produkt und Kriterium der inneren Tiefe. Ich habe viele neuere Schriftsteller geliebt, die diesem Ideal stilistisch entgegengesetzt sind. Wenn ich aber selber schreiben muss, kann ich nur meinen eigenen stilistischen Neigungen folgen, um mein eigenes Denken in die angemessenen Kanäle einzugießen. Und gerade die Strukturierung meines Denkens führt mich in die Nähe des transparenten und möglichst schlichten Stils, und zwar weil dann, wenn es sich um theoretische Texte handelt, die geistige Ehrlichkeit es verbietet, Mängel des Denkens mit Verblümungen und lexikalischen Seiltänzen zu überdecken. Insbesondere bietet die Sprache, in der ich ursprünglich meine Bücher schreibe, dem Kenner der klassischen Sprachen außerordentliche Vorteile: Die deutsche Sprache enthält weit mehr als andere Sprachen die syntaktischen Strukturen und lexikalischen Modi der altgriechischen und der lateinischen Sprache. Insbesondere die fast unbeschränkten Möglichkeiten der Verbindung von Haupt- und Nebensätzen innerhalb längerer Satzperioden erlauben die präzise Formulierung mehrschichtiger Gedanken, wo in der syntaktischen Verbindung reliefartig die Verknüpfung und das Gewebe der Beziehungen zwischen den verschiedenen Dimensionen des Sinns ausgedrückt werden. In keiner anderen der mir bekannten Sprachen kann z.B. so gut der Stil des Thukydides wiedergegeben werden. 
głębi. [...] To właśnie strukturyzacja mojego myślenia prowadzi mnie do przejrzystego i możliwie prostego stylu, a w tworzeniu teorii intelektualna szczerość zabrania przykrywania braku myślenia upiększeniami i leksykalnym tańcem na linie. Język, w którym początkowo pisałem książki, oferuje osobom znającym języki klasyczne niesamowite korzyści: język niemiecki zawiera dużo mniej niż inne syntaktycznych struktur i leksykalnych modyfikatorów, właściwych dla języka starogreckiego i łacińskiego. [...] W żadnym ze znanych mi języków nie może tak dobrze zostać oddany styl np. Tukidydesa.

Pojęcia muszą być nasycone doświadczeniem, muszą więc osiagnąć idealizację lub typizację doświadczenia, aby były użyteczne dla dalszego tworzenia teorii. Jak jest to trudne, wyraźnie Kondylis wykazał na przykładzie dalszych etapów pracy, które musiał wykonać Clausewitz, aby stworzyć swą ponadczasową teorię wojny. Jest ona ponadczasowa, ponieważ odwołuje się do stałych antropologicznych. Najpierw Clausewitz był pod wrażeniem bitew napoleońskich, które dokładnie przeanalizował, następnie przeszedł do obszerniejszych analiz innych bitew i wojen, aż końcu zdobył niezbędne doświadczenie, by stworzyć teorię.

Specyfika określonego fenomenu, dla Clausewitza była nim wojna, wynika wówczas, gdy widoczna jest dzięki procesowi abstrakcji; w przypadku wojny należy przewidzieć, co utrudnia uwiecznienie i wszechobecność wrogości i zewnętrznej przemocy.

Clausewitz wskazuje przy tym na następujące czynniki antropologiczne: człowiek posiada podwójną naturę; ponieważ z jednej strony charakteryzuje go wrogość wobec innych, z drugiej zaś jest słaby, niepewny i bojaźliwy. Tak więc chęć walki i panowania stoją po jednej stronie a bojaźliwość i niezdecydowanie człowieka po drugiej. Dzięki abstrakcji Clausewitz może otrzymać w końcu „czyste” pojęcia.

Każdy uczy się na podstawie doświadczenia, tworząc swą małą teorię codzienności; przecież szeroko pojmowana teoria rzeczywistości nie jest jedynie konstrukcją logiczną, lecz wymaga, aby długo ćwiczyć się w obserwacji ludzkich spraw i być $\mathrm{w}$ stanie $\mathrm{z}$ wyczuciem uporządkować bogaty materiał $\mathrm{w}$ doświadczeniu. Tak w praktyce, jak i w teorii decydująca jest owa zdolność oceny, w której w pełni rozwijają się i harmonijnie współdziałają duchowe możliwości i zdolności podmiotu (por. Theorie des Krieges, s. 99-100).

Clausewitz posługuje się tu pojęciem zdolność oceny, które przypomina „poczucie taktu”; w „zdolności oceny” uczucie i rozsądek czy doświadczenie są nierozerwalnie ze sobą powiązane i nie dają się już od siebie odróżnić. 
Znaczące jest przy tym, że na podstawie długiej praktyki powstaje zdolność, która pozwala w intuicyjny sposób ocenić stan rzeczy. Poeta Heinrich von Kleist, współczesny Carlowi von Clausewitzowi, opisał ją w sposób obrazowy: „z późniejszej perspektywy uczucie stopniowo kształtowane jest przez rozum na podstawie doświadczenia" (Heinrich von Kleist, Von der Überlegung Eine Paradoxe).

Taką nadzwyczajną „zdolnością oceny”, co można wywnioskować na podstawie źródeł historycznych, dysponowała np. Joanna d’Arc, która jako prosta dziewczyna zajmująca się pasterstwem rozpoznała nieznanego jej króla w tłumie sług, jako tego, który wmieszał się w świtę królewską, podczas gdy służący zajmował jego miejsce na tronie. To „regulowane” uczucie - lub patrząc $\mathrm{z}$ innej strony powstała przez doświadczenie zdolność właściwej oceny nie może być mylona z pojęciem „wczucia się". Prawdopodobnie nigdy nie dowiemy się, gdzie przebiega granica między geniuszem a nawet najlepszą przeciętnością. Z pewnością nie pokrywa się ona jednak z granicą pomiędzy refleksją a wczuciem się, zwłaszcza, że nie możemy wiedzieć, czy myślenie uznawane za racjonalne rzeczywiście takie jest. „Być może geniusz charakteryzuje się właśnie tym, że ktoś w sposób uzasadniony, a więc na podstawie swoich własnych osiągnięć, potrafi wznieść się ponad takie sprzeczności” (Das Politische und der Mensch. Grundzüge der Sozialontologie, t. 1, s. 380). To stwierdzenie odnosi się wprawdzie do Clausewitza, ale można je równie dobrze odnieść do Kondylisa. Już jako uczeń miał on właściwą zdolność oceny, rozpoznając antropologiczne zaplecze teorii Tukidydesa, Machiavellego czy Hobbsa jako odpowiadające rzeczywistości. Jest to jedna z przyczyn, dla których nie musiał poddawać swoich prac jakimkolwiek zmianom, a mimo to do dziś sprawiają one wrażenie bardzo spójnych.

Przełożyła Anna Ziółkowska, przekład przejrzeli Adam Grzelińki i Lech Zieliński

\section{Bibliografia}

Flügel-Martinsen O., Apokiktischer Dezisionismus? Kondylis` Machtdenken, „Deutsche Zeitschrift für Philosophie“, 2013, 3, Berlin, s. 365-385.

Gabiś T., Panajotis Kondylis, „Nowe Państwo” 3/2006. 
Kleist von H., Von der Überlegung [Eine Paradoxe], [w:] Werke und Briefe in vier Bänden, t. 3, Frankfurt/Main, 1986, s. 471-472.

Kondylis P., Die Entstehung der Dialektik. Eine Analyse der geistigen Entwicklung von Hölderlin, Schelling und Hegel bis 1802, Stuttgart 1979.

Kondylis P., Die Aufklärung im Rahmen des neuzeitlichen Rationalismus, Stuttgart 1981, Hamburg 2002.

Kondylis P., Macht und Entscheidung. Die Herausbildung der Weltbilder und die Wertfrage, Stuttgart 1984.

Kondylis P., Konservativismus. Geschichtlicher Gehalt und Untergang, Stuttgart 1986.

Kondylis P., Theorie des Krieges. Clausewitz - Marx - Engels - Lenin, Stuttgart 1988.

Kondylis P., Die neuzeitliche Metaphysikkritik, Stuttgart 1990.

Kondylis P., Der Niedergang der bürgerlichen Denk- und Lebensform. Die liberale Moderne und die massendemokratische Postmoderne, Weinheim 1991.

Kondylis P., Planetarische Politik nach dem Kalten Krieg, Berlin 1996.

Kondylis P., Montesquieu und der Geist der Gesetze, Berlin 1996.

Kondylis P., Das Politische und der Mensch. Grundzüge der Sozialontologie, t. 1: Soziale Beziehung, Verstehen, Rationalität, Berlin 1999.

Kondylis P., Das Politische im 20. Jahrhundert. Von den Utopien zur Globalisierung, Heidelberg 2001.

Kondylis P., Machtfragen, Darmstadt 2006. (reprint „Macht und Entscheidung“ $i$ „Wissenschaft, Macht und Entscheidung").

Kondylis P., Machiavelli, Berlin 2007.

Koselleck R., Kondylis’ Beiträge zu den "geschichtlichen Grundbegriffen“, [w:] Falk Horst (red.) Panajotis Kondylis. Aufklärer ohne Mission. Aufsätze und Essazs, Berlin 2007, s. 1-14.

Terpstra M., Interview: Skeptische Wahrheitssuche gegen normative Entscheidung, [w:] Panajotis Kondylis, Machtfragen. Ausgewählte Beiträge zur Politik und Gesellschaft mit einer Einleitung von Volker Gerhardt, Darmstadt 2006, s. 157-171.

Wrazas I., Nihilizm i teoria. Panajotisa Kondylisa dyskryptywna teoria decyzji, „Nowa Krytyka”, 18/2005.

\section{Abstract \\ Observation of Reality and Theory Creation in Panagiotis Kondylis' Thought}

In the first part of the paper the authors present an outline of the Polish perception of thoughts and ideas of Panagiotis Kondylis which has started to develop only recently. This is followed by demonstrating major issues present in the output of this 
Greek philosopher who was strongly linked both with Greece (Athens) and with Germany (Heidelberg). The paper closes with a discussion of Kondylis' concept of theory creation demonstrated in his work entitled Theorie des Krieges. Clausewitz Marx - Engels - Lenin (Theory of War. Clausewitz - Marx - Engels - Lenin) which was published in Stuttgart in 1998. Although the very foundation of his ideas is the theory of war by Carl von Clausewitz whom Kondylis perceived as a conceptual soul mate, the discussion per se is of a more universal nature and may pertain to the essence of developing any theory. The paper is to help the Polish reader to understand the ideas and thoughts of Kondylis, and thus to facilitate the perception of translations of his texts that were published in Studies in the history of philosophy.

Key words: Panagiotis Kondylis, theory of war, theory creation, skepticism, relativity of values 